\title{
Sustainability assessment of food supply chains: an application to local and global bread in Italy
}

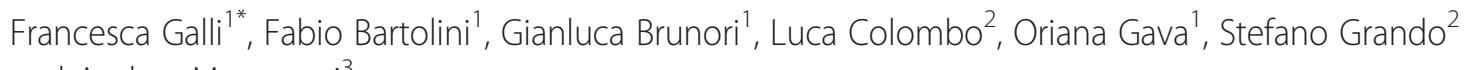
and Andrea Marescotti ${ }^{3}$

\author{
* Correspondence: \\ francesca.galli@for.unipi.it \\ This paper has been selected as a \\ best paper of the 51th SIDEA \\ Conference in Benevento (18-20 \\ September 2014). It has been \\ accepted for publication in this \\ journal following the usual revision \\ process. \\ ${ }^{1}$ Department of Agriculture, Food \\ and Environment, University of Pisa, \\ via del Borghetto 80, 56124 Pisa, \\ Italy \\ Full list of author information is \\ available at the end of the article
}

\begin{abstract}
Over the 2000s', consumers' food purchases have been increasingly informed by supply chain-related issues, with growing concerns about the sustainability of chains differing for their geographical scope. As a result, short food supply chains and local food systems have risen to policymakers and food chain stakeholders' attention as more sustainable alternatives to mainstream food networks. However, associating food chain's geographical scope and sustainability performance may not be straightforward. This paper aims at shedding lights on the connection between geographical scope and sustainability by comparing and discussing 19 attributes owing to different sustainability dimensions. The analysis anchors on the wheat-to-bread chain, due to its global relevance. Bread is a worldwide staple food and wheat is (generally) a commodity traded globally. However, wheat processing often occurs locally and baking is influenced by local heritage and consumption patterns, particularly in the EU and in Italy, where gastronomy is culturally embedded. The paper identifies critical aspects and provides a qualitative assessment of the performances of local vs global wheat-to-bread chains. The assessment is carried out on Italian case studies.
\end{abstract}

Keywords: Sustainability assessment; Food supply chain; Local; Global; Bread JEL: Q18 Agricultural Policy; Food Policy; Q10 General

\section{Background}

The emerging evidence of global food chains' negative sustainability and nutritional performance are among the underlying determinants of raising consumers' concern about food origin (Ilbery and Maye, 2005; Goodman et al., 2010). That trend has somewhat strengthened the position of policymakers and food chain stakeholders supporting food "relocalization" world-wide (e.g. Forssell and Lankoski, 2014; Ilbery and Maye, 2006; Selfa and Qazi, 2005, O'Hara and Stagl, 2001). Business, concerned citizen organizations, and policy initiatives have boosted the diffusion of short food chains and local food systems, which, in turn, have stimulated research and policymaking (see, for example, Martinez et al., 2010; Kneafsey et al., 2013). Many academic studies have

\section{Springer}

(c) 2015 Galli et al. Open Access This article is distributed under the terms of the Creative Commons Attribution 4.0 International License (http://creativecommons.org/licenses/by/4.0/), which permits unrestricted use, distribution, and reproduction in any medium, provided you give appropriate credit to the original author(s) and the source, provide a link to the Creative Commons license, and indicate if changes were made. 
assessed the sustainability of food chains, but no agreement has been reached about the overall sustainability performance of local food systems (see Hand and Martinez, 2010 and Durham et al., 2009).

Indeed, those assessments are challenging in their attempts to integrate food production-to-consumption impacts in comprehensive decision making tools, able to highlight tradeoffs and ethical dilemmas. However, the scientific community has not yet agreed on a shared methodology, allowing robust and simultaneous comparisons over all sustainability dimensions. Despite the global importance of food chain alternatives to the mainstream (global) food system, here, we concentrate on the EU context. We propose a multidimensional sustainability assessment based on a set of 19 criteria. Provided the impact of food choice on human health and ethical concerns associated to food consumption, we considered those two social issues as autonomous dimensions of sustainability, thus ending with five sustainability dimensions. After a preliminary literature review, we develop a comparative case study research considering two Italian wheat-tobread chains differing for their geographical scope, and summarise research findings into a matrix, that helps discriminate local and global chains for their relative sustainability performance. The paper is structured as follows: firstly, we introduce the methods; secondly, we describe the Italian bread sector and introduce the two case studies; thirdly, we present and discuss the comparative assessment matrix. The concluding paragraph summarises our findings, highlighting strengths and weaknesses of our work, and providing insights for further research.

\section{Methods}

This paper has the objective of exploring the sustainability dimensions relevant for the performance assessment of the supply-chains, with a special focus on the wheat-tobread supply chains. It aims at providing a qualitative assessment on the expected performance contrasting local versus global wheat-to-bread chains, based on evidence gathered on two case-studies. ${ }^{1}$ This contribution represents the first step, preliminary to the further assessment of the most critical attributes here identified, that shall be based on evidence provided by indicators selection and measurement.

The methodology used entails three main steps: i) analysis of academic literature to identify the critical links between a pre-defined set of sustainability attributes and the wheat-to-bread chain ii) mapping of a local and a global bread supply chain in terms of globalness/localness. iii) Expert qualitative assessment of the supply chains case-studies with regard to the ability of the selected sustainability attributes to discriminate between local and global, and preliminary evaluation on the best performing supply chains.

Regarding the first step, the identification of sustainability attributes stems from the work of Kirwan et al. (2014). The authors, based on national level reports carried out a European wide systematic analysis on how both local and global food and the performance of food chains are perceived, defined and communicated in the public, scientific, market and policy spheres (regarded as arenas of interaction and debate) across the five mentioned sustainability dimensions. A set of 24 attributes, representing the most relevant societal expectations on food supply chain performances, has been identified through a process of selection and aggregation of the attributes identified at national level in the countries examined. Out of the 24 general attributes we have selected 19 
suitable to discuss the sustainability of the wheat to bread supply chain ${ }^{2}$ (Table 1 ). The allocation of the attributes within the five dimensions of sustainability reflects the one suggested by the authors.

The sustainability dimensions considered by the authors aim at encompassing not only the social, economic and environmental and but also ethical and health dimensions. Although 'localness' of food is connected to 'healthiness' by association with freshness, seasonality and trust (IGD 2008) the health aspect of the local-global dimension in food is poorly communicated and remains implicit rather than explicit. Similar arguments are valid for the analysis of ethical performance in the food chain, which has concentrated on values-based purchasing and alternative economic experiments, notably alternative food networks (AFNs), fair trade practices, product certification schemes (i.e. animal welfare), and Slow Food and food sovereignty movements (Barnett et al., 2010; Maye and Kirwan, 2010). Given the difficulty in defining ethical issues, so far few attempts have been made to assess the performance of supply chains on the ethical dimension.

The review of academic literature referred to the wheat to bread chain is developed according to a systematic approach (Fink, 2014; Pfau et al., 2014). To this end, we created suitable strings by combining each attribute (and synonyms) with the terms "bread", "wheat" "soft wheat" and integrated results from Scopus, Ageconsearch and Google Scholar databases. The search was performed in September 2014. We selected 92 references based on the pertinence and relevance with respect to each attribute. This allowed framing the most critical issues emerging in the wheat to bread supply chain

Table 1 Attributes for sustainability assessment

\begin{tabular}{ll}
\hline Dimensions of sustainability & Attributes \\
\hline Economic & Affordability \\
Environmental & Biodiversity \\
Social & Connection and labour relations \\
Social & Consumer behavior \\
Economic and environmental & Economic and ecological efficiency \\
Economic & Farmers income and value added received \\
Social and ethical & Food security \\
Economic and ethical & Governance/even distribution of power \\
Social & Information and Communication \\
Health & Nutrition \\
Economic & Profitability/competitiveness \\
Economic & Resilience and local development \\
Environmental & Resource use and pollution \\
Ethical & Responsibility \\
Health & Safety \\
Economic & Technological innovation \\
Social and ethical & Territoriality \\
Health & Traceability \\
Environmental and economic & Waste \\
\hline Souce: adad from Kirat &
\end{tabular}

Source: adapted from Kirwan et al. 2014 
for each attribute (see Gava et al., 2014 for a review). In the second step, we identified two wheat to bread chains differentiated on the basis of four key criteria drawn from academic literature to distinguish between global and local food chains: i) the physical/ geographical distance between production and consumption (i.e. the food miles concept, Pretty et al., 2005; Hogan and Thorpe, 2009). This is a primary distinction, with emphasis on the place of cultivation of wheat with respect to milling and baking and consumption. ii) The type of governance and organization of the supply chain, in particular the degree of control on the chain exerted by "local actors" vs "global actors" (Marsden, 2000; Ménard and Valceschini 2005; Gellynck and Molnár 2009). iii) The type of resources, knowledge and technologies employed (Wiskerke, 2003), in particular the technology used for flour milling and baking technique. Also the ingredients and the complexity of the recipe often discriminate among industrial and artisanal breads. iv) The way supply chain actors shape product identity with regard to territory of reference: quality attributes of bread vary in relation to territorial typologies, traditions, local culture (Marsden and Smith, 2005; Tregear, et al., 2007, Barham and Sylvander 2011). The selected case studies were then analysed on the basis on in-depth interviews with stakeholders at each step of the chain (agricultural production, storage, milling, baking and retailing), and integrated with secondary data readily available (i.e. company reports, newspapers, websites).

In the third step we turned to selected experts asking them to formulate an assessment on the ability of each selected sustainability attributes to discriminate across local and global chains, and to give a preliminary assessment on the best performing supply chain (local or global) in relation to each attribute. We interviewed eight experts, chosen to cover as many scientific domains as possible: one academic in plant genetics, one in food technology, an NGOs active in seed saving networks, a regional policy maker, one expert artisanal baker and one expert industrial baker, an innovation manager for industrial bakery, a quality manager for a large retailing company.

The output of this preliminary analysis is given by a synthetic, qualitative assessment on the performance variability of two chains with respect to each attribute and an assessment on which out of the chains studied shows the best expected performance.

\section{Results}

\section{The bread sector in Italy}

Bread is a staple food of worldwide importance. Bread basic ingredients are cereal flour, water, a leavening agent, and salt. The bread supply chain involves both global and local phases, from input production to consumption. The production process involves wheat grinding and baking; both processing stages can occur in small scale (artisan) or large scale (industrial) plants. Apart from the difference in scale (amount of raw material and end-product handled and delivered) the artisan production systems normally differ from the industrial ones for technology and environmental impact (Espinoza-Orias et al., 2011; Andersson and Ohlsson, 1999; Mondal and Datta 2008).

Italy is a country where bread baking has a long standing cultural tradition (Pagani et al., 2014).

Italy produces and consumes around 3.2 million tons of bread per year, worth 8 billion euro. Out of this, $90 \%$ is produced in artisan bakeries, and the $10 \%$ is 
industrial, although in terms of value industrial bread retains a higher portion of turnover (over one billion euro). Traditionally, Italians buy bread directly from local bakeries, who pack the loaves in paper bags. Despite regional and local varieties, there are general features, such as crispy crust and relatively short shelf life. There are more than 300 varieties of local breads in Italy and each region has a particular recipe and tradition, which varies in relation to wheat cultivar, flour class and raising method, baking, shape and size of the loaves, along with salt quantity. Industrial bread is normally a soft loaf, with a shelf life up to 40 days. It is sliced, packed with plastic and mainly sold by supermarkets. It is mostly used as a substitute product (e.g. when running out of freshly baked bread) or for eating out. While the handcraft bread production is scattered on the Italian territory, the industrial baking sector is highly concentrated (the top three companies own a total share of $37.4 \%$ of the market, while private labels account for $13.5 \%$ ). Over the last years, consumer prices have been highly variable (from $€ 1,70$ to 3.94 per $\mathrm{kg}$ in the south and north of Italy), depending on bread type, quality and marketing channel. In recent years, re-localization initiatives have spread (Hills et al., 2013) also in Italy, as indicated by the emergence of geographical indications (PDO and PGI) as well as the proliferation of spontaneous initiatives promoting local wheat-to-bread chains and value added bakery products.

The case selected studies represent different types of production, consumption and governance of the wheat to bread chain: the global industrial chain is represented by the Barilla soft bread case and the local bread chain takes place on Floriddia family farm, in the province of Pisa, in all its stages from input production to distribution.

\section{Mapping the global chain case study}

The global wheat to bread chain is led by Barilla a multinational group that stands as one of the top Italian food groups, leading company for pasta production, bakery products and processed sauce market of continental Europe, and the flatbread market in Scandinavia. Out of its various brands, Mulino Bianco ${ }^{\circ}$ Pan Bauletto (hereinafter Pan Bauletto) is a leader product in the sector of industrial pre packaged bread in Italy. Such industrially produced bread is made of soft wheat flour (obtained from grains produced in Italy and abroad), water, salt yeast and vegetable oil. This soft bread is marketed exclusively at national level, which is what normally happens on the bread markets. Indeed, this bread is in fact very different from the "local" bread we studied, in terms of consumption habit: Pan Bauletto is suitable for snacks or as a substitute of freshly baked bread whereas local bread is mainly consumed during meals.

Figure 1 is an elaboration on a framework by World Food System Center ${ }^{3}$ (WFSC) that can help placing information on a gradient along the food supply chain. It shows the main steps occurring through the chain (in columns), and places them on a local to global scale (in rows) for a visual interpretation, identifying the different flows going through the steps at different scales.

The upstream stages of the Pan Bauletto bread chain (i.e. imports of soft wheat, and other primary inputs) occur at continental level while the following stages occur at the national level. Fuel supply, machinery and energy represent the most global inputs throughout the chain, although not as specific as wheat. Barilla company both sources 


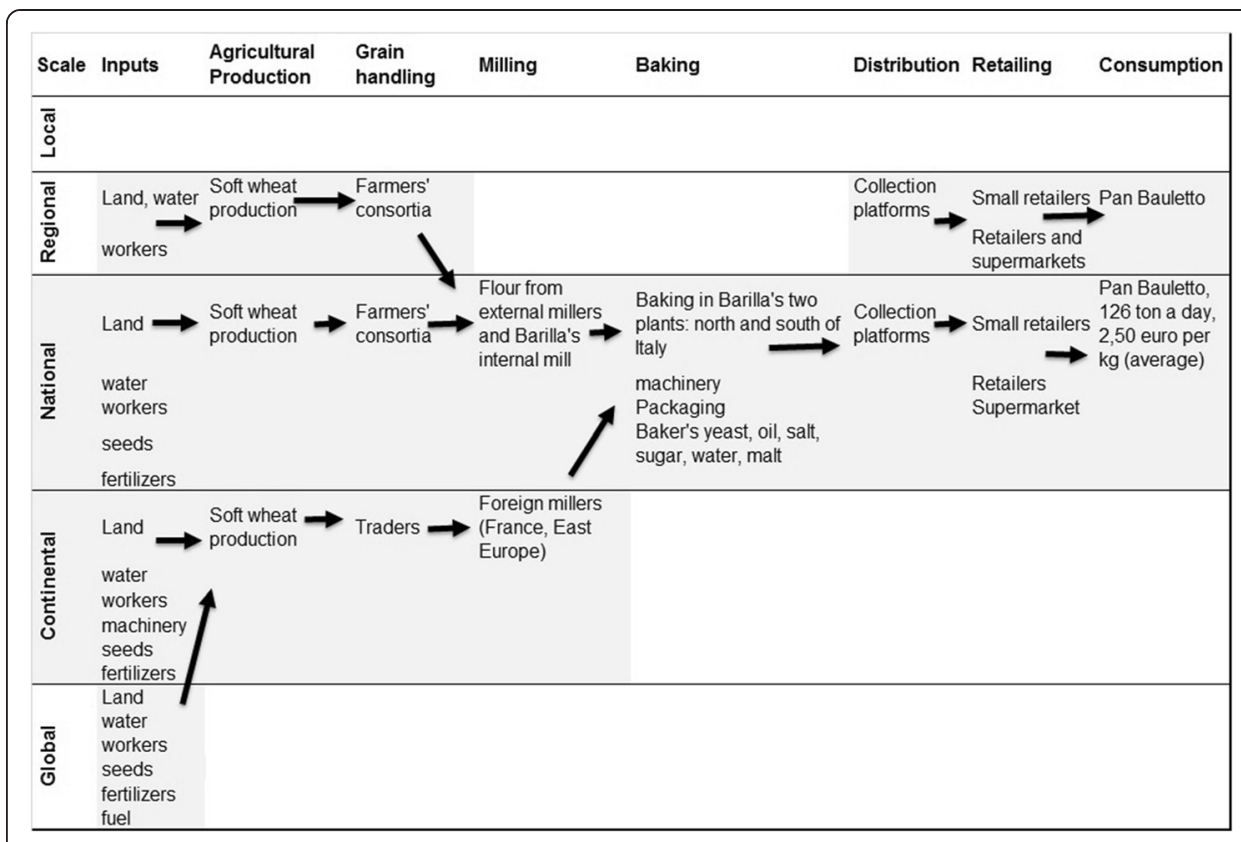

Fig. 1 Wheat to bread supply chain: WFSC framework for the global chain. Source: authors' elaboration on Food supply chain framework. It is a representation of the main steps of the supply chain analysed on a gradient from local to global

soft wheat for internal milling (30 \%) and buys flour directly from other milling companies $(70 \%)$. Soft wheat supplies are based on production contracts with farmers according to specific quality specifications (or specific varieties that have the desired characteristics). The price is set on the basis of the commodity board of exchange or bargained at the beginning of the season: it may vary according to the amount purchased, and a premium price is granted when the farmers comply with Barilla's specification on wheat growing and storage and/or the wheat displays some specific quality characteristics. The requirements are strict because the industrial baking process cannot be adjusted "manually" (as the handcraft baker would do). Hence, there is the need for highly standardized raw material suitable for specific dough rising times and strength of flour. For flour, Barilla refers to three main millers with whom it makes contracts from 3 to 6 months. In this case it is not possible to know the exact origin of the grain. The main suppliers of flour are Italian, because flour is highly perishable during transportation. The production process occurs in two plants based in the North and South of Italy (i.e. Cremona and Melfi, respectively). Secondary processes include mixing of raw ingredients (flour, water, salt and yeast) to form a dough; bulk fermentation, division of dough into individual loaf-sized pieces, molding, proofing; baking of pieces in gas oven; cooling and packaging; production of packaging material; delivery of products to distribution platforms. Distribution channels of packaged soft bread entail large scale distribution for most part (75\%) then there are individual traders and retailers, all over Italy. The price list is national, there are discounts and promotions depending on the local market. Production processes allow a long shelf life (over 45 days) without the use of preservatives: at the end of the process the loaves are kept in sterile rooms, without any contamination and with addition of a splash of ethanol (a mild antibacterial). The longer shelf life of the product allows very low levels of waste at the 
distribution and consumption levels. Differently from what happens to industrial bread production in other countries, this long shelf-life is due to the peculiarity of the Italian bread market: indeed, the Italian consumers normally use industrial bread in the absence of freshly baked bread.

\section{Mapping the local chain case study}

The local bread supply chain takes place on one single farm, located in the province of Pisa (rural area in central east part of Tuscany) from cultivation of grains to milling, baking and final sale of bread loaves (among other bakery products). Figure 2, the different steps on a scale, from local to global.

Floriddia family farm extends for more than 300 hectares, and employs 12 full time workers. Originally founded by their father, today the farm is led by Rosario and Giovanni, the two sons. The farm turned to organic agriculture in 1987, then started to experiment with the cultivation of ancient varieties of wheat and gradually decided to invest on farm milling and baking facilities. Thanks to the collaboration with the Rural Seed Network and the local association for organic farming, Floriddia experienced that the old varieties in rotation with legumes can achieve excellent results in terms of yields and decided to devote all its land to it. Technologically advanced milling and baking facilities have represented a major investment, partially funded by EU rural development scheme. Milling and baking activities are keen on preserving the nutritional value of wheat, allowing processing of low gluten, wholegrain flours and sourdough for fermentation. Customers are varied: from individual private companies mainly operating in the catering industry (restaurants, pizzerias, gastropubs, shops) and solidarity purchasing groups (i.e. gruppi di acquisto solidale, GAS) who regularly purchase through the website. The ecommerce service is available to any customers throughout the country but it is also possible to buy the products directly on farm.

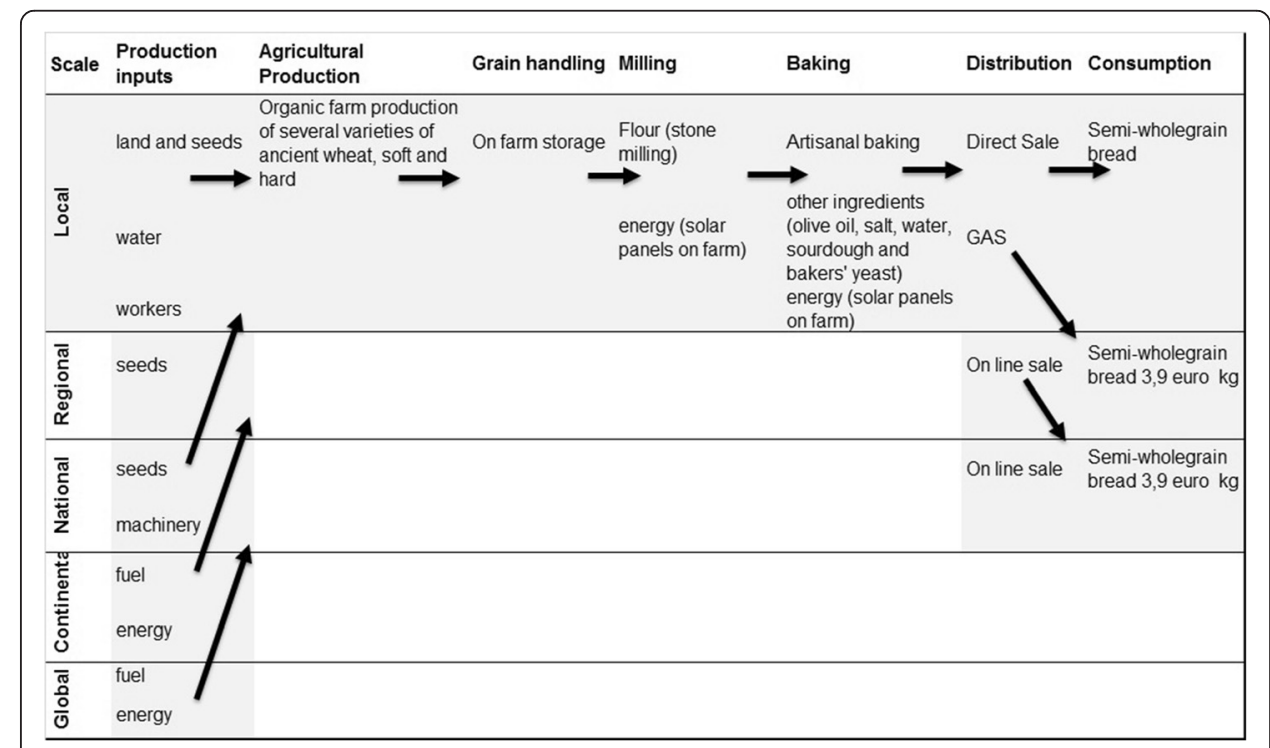

Fig. 2 Wheat to bread supply chain: WFSC framework for the local case. Source: authors' elaboration on Food supply chain framework. It is a representation of the main steps of the supply chain analysed on a gradient from local to global 


\section{Discussion: the comparative assessment matrix}

Table 2 indicates the attributes (in alphabetical order) in the first column, then the emerging themes from the academic literature (second and third columns). The analysis of available literature allows to pinpoint some critical issues: these provide a focus for the assessment of the chains selected against the broad meaning of each attribute. The next columns indicate, respectively, a synthetic evaluation on the differences of performance between the two chains (high, medium or low) and a preliminary hypothesis on which chain displays the best performance, based on collected evidence and the assessment by the experts.

To be noted that some attributes find more room within the literature on wheat to bread chain than others do, which gives an indication on the relevance of each attribute in relation to this chain. This is also because attributes are closely connected to each other, and overlap to some extent, as for example "information", "communication" and "traceability", in relation to the "identity preservation" of wheat. There are connections among attributes that upraise relevant research issues, too. For example, "affordability" of bread, is framed in relation to "consumer behaviour" and "nutritional value and healthiness". "Efficiency" is debated in relation to environmental impacts, beyond mere economic terms, and so on. Some other attributes, such as "food security", represent wider "umbrella" concepts (or frames, see also Mooney and Scott, 2009) that cover a wide range of other (sub) attributes, such as "technological innovation", "safety" or "waste", as well as "nutrition" and "biodiversity".

Moving to the sustainability performance of the two chains, based on available evidence and expert evaluation, overall local and global chains perform more or less well with respect to different sets of attributes. The two chains show an expected "complementary" sustainability performance. In other words, the local chain shows a better performance on spheres where the global is more constrained, and vice versa. The global chain shows a good performance in relation to all attributes that are positively correlated to scale. Moreover, the global chain has an advantage in terms of environmental impact (resource use and pollution, see Barilla 2012) and constraints in terms of food safety. It also relies on pervasive marketing communication strategies and continuous innovation investments, to safeguard its market performance. Furthermore, it shows good affordability for the consumer in terms of low price per kilo and accessibility of the product, marketed mainly through mass distribution. Less clear is whether such price affordability is combined with high nutritional value. Moreover, biodiversity and genetic improvement of wheat cultivars represent controversial matters and further investigations and reliable indicators should be defined in this sense.

The local chain case study is expected to perform better on other aspects of sustainability. For example, biodiversity is emphasized as a management strategy and the farmer explicitly refers to biodiversity protection when describing the farming system, seeds' selection, and bread wheat processing. In addition, farmer's added value received for wheat and bread is expected to be higher than in the other chains. The local bread is a niche product, with peculiar features and the farmer asserts that the price is fixed on the basis of production costs, which allows him to be economically sustainable. This however does not imply economic efficiency, as the farmer states that he activates the milling plant in relation to market demand for flour and bread, but quite below the production potential. In terms of information and communication, at the local level a 
Table 2 Sustainability attributes for the wheat to bread chain and assessment on difference and performance

\begin{tabular}{|c|c|c|c|c|}
\hline \multirow[t]{2}{*}{ Attribute } & \multicolumn{2}{|l|}{ Literature analysis } & \multicolumn{2}{|c|}{ Expert judgment } \\
\hline & Critical aspect & Academic literature on bread chains & Differences $^{\mathrm{a}}$ & Supply chain with best (expected) performance \\
\hline Affordability & $\begin{array}{l}\text { Access to nutritious and healthy bread for } \\
\text { low income families, or across cities and } \\
\text { city areas or in developing countries }\end{array}$ & $\begin{array}{l}\text { Smith et al. 2013; Flynn et al. 2012; } \\
\text { Olaoye et al. 2011; Mason et al. 2011; } \\
\text { Lopez-Class and Hosler, 2010; Caraher et al. } \\
\text { 2010; Duvenage and Schönfeldt, } 2007\end{array}$ & +++ & $\begin{array}{l}\text { Global bread is widely available and } \\
\text { affordable in supermarkets, very often } \\
\text { at promotion prices }\end{array}$ \\
\hline \multirow[t]{2}{*}{ Biodiversity } & Decrease in soft wheat genetic diversity & \multirow{2}{*}{$\begin{array}{l}\text { Bonnin et al. 2014; Coda et al. 2014; Bonneuil } \\
\text { et al. 2012; Dawson et al. 2012; Gallo } \\
\text { et al. 2009; Falco et al. } 2008\end{array}$} & \multirow[t]{2}{*}{+++} & \multirow{2}{*}{$\begin{array}{l}\text { The local organic farmer cultivates several } \\
\text { ancient landraces and populations, while } \\
\text { the global chain cannot use them due } \\
\text { to supply shortage and instability, and } \\
\text { technical characteristics }\end{array}$} \\
\hline & $\begin{array}{l}\text { Evolution of bread wheat varieties in organic } \\
\text { farming, Ancient varieties of wheat and } \\
\text { sourdough fermentation. }\end{array}$ & & & \\
\hline \multirow[t]{2}{*}{ Connection } & $\begin{array}{l}\text { Role of social relationships in organic cereal } \\
\text { networks. Embeddedness in conventional } \\
\text { and alternative bread supply chains }\end{array}$ & \multirow[t]{2}{*}{$\begin{array}{l}\text { Milestad et al., 2010; Magnan, 2011; } \\
\text { Penker, } 2006\end{array}$} & \multirow[t]{2}{*}{+} & \multirow{2}{*}{$\begin{array}{l}\text { Both local and regional chains are highly } \\
\text { integrated. The local chain produces the } \\
\text { main ingredient while the global chain } \\
\text { strictly monitors suppliers }\end{array}$} \\
\hline & $\begin{array}{l}\text { Identity preserved sourcing relationships } \\
\text { between farmers and bakeries for quality }\end{array}$ & & & \\
\hline Consumer behavior & $\begin{array}{l}\text { Consumption in relation to health and nutritional } \\
\text { information. Consumer behavior by vulnerable } \\
\text { societal groups (pregnant women, children, poor) }\end{array}$ & $\begin{array}{l}\text { Hellyer et al. 2012; Barre et al., 2011; } \\
\text { Freedman and Bartoli, } 2013\end{array}$ & +++ & $\begin{array}{l}\text { Local and global breads have very different } \\
\text { consumption uses. }\end{array}$ \\
\hline \multirow[t]{2}{*}{$\begin{array}{l}\text { Economic and ecological } \\
\text { efficiency }\end{array}$} & $\begin{array}{l}\text { Genetic progress in wheat yield in relation } \\
\text { to nitrogen use. }\end{array}$ & \multirow[t]{2}{*}{$\begin{array}{l}\text { Khatir et al. 2013; Tsegaye, 2012; Ortiz- } \\
\text { Monasterio et al. } 1997\end{array}$} & \multirow[t]{2}{*}{+++} & \multirow{2}{*}{$\begin{array}{l}\text { Global chain's scale of production allows } \\
\text { economies of scale, also from an } \\
\text { environmental point of view. }\end{array}$} \\
\hline & $\begin{array}{l}\text { Improvements in baking ovens for better } \\
\text { energy efficiency }\end{array}$ & & & \\
\hline $\begin{array}{l}\text { Farmers income and } \\
\text { value added received }\end{array}$ & $\begin{array}{l}\text { Role of farmers' cooperatives for aggregation, } \\
\text { increased yields, adaptation to scarcity and } \\
\text { impact of subsidy policies, price transmission } \\
\text { along the chain. }\end{array}$ & $\begin{array}{l}\text { Rumánková, 2014; Cacchiarelli et al. 2013; } \\
\text { Bardsley and Bardsley, 2014; Jat et al. 2014; } \\
\text { Schenk et al. 2014; Pan et al. 2014; } \\
\text { Li and Rui, 2013; Kimura et al. } 2010\end{array}$ & ++ & $\begin{array}{l}\text { Local chain fixes price in relation to production } \\
\text { costs, global chain refers to global market prices }\end{array}$ \\
\hline Food security & $\begin{array}{l}\text { Increased wheat productivity, conservation of } \\
\text { adaptable local landraces, political instability, } \\
\text { impact of biofuel on food availability, sustainability. }\end{array}$ & $\begin{array}{l}\text { He et al. 2013; Özbek 2014; Mujeeb-Kazi et al. } \\
\text { 2013; Ahmed et al. 2012; Sternberg 2012; } \\
\text { Azapagic et al. 2010; Pimentel et al. 2009; }\end{array}$ & + & $\begin{array}{l}\text { Food security is a transversal issue. The three } \\
\text { chains can be interpreted according to } \\
\text { different "food security frames" } \\
\text { (Mooney and Scott, 2009) }\end{array}$ \\
\hline
\end{tabular}


Table 2 Sustainability attributes for the wheat to bread chain and assessment on difference and performance (Continued)

Governance/even

distribution of power

Governance responses to socio ecological risk

Increased transparency in the chain.

Information and communication Effects of information on consumer

preference (e.g. functional ingredients).

Consumer perception of bread quality,

organic vs conventional bread.

Nutrition

mpacts of ingredients, baking methods, and types of bread on health (salt reduction, wholegrain, variety of grains, fiber). Potential of sourdough fermentation and baking techniques to improve nutritional properties of bread.

Fortification of staple foods.

Consumer attitude towards gluten free products

Value of label design and nutritional labeling format on consumer attention.

Profitability for farmers, processors and retailers/ Competitiveness

Resilience and local development
Selection decisions on healthier foods by retailers in terms of profitability

Competition enforcement in the wheat to bread sector to guarantee lower prices for consumers. Concentration in the milling and baking sectors as barriers to market entry

Innovative governance responses to socio-ecological risk and roles of cooperatives; Benefits for production, resilience and conservation of biodiversity
Hellyer et al. 2012; Gellynck et al. 2009;

Annett et al. 2008; Kihlberg et a . 2005;

Antúnez et al. 2013; Talaei et al., 2013;

Békés, 2012; Belz et al. 2012; Jones, 2011;

Dewettinck et al. 2008: Katina et al. 2005;

Yusufali et al. 2012; Ozola and Straumite, 2012
Decision power is concentrated in both

chains. The local chain is highly transparent oriented to managing socio-ecological risks. The global chain is much more articulated: it aims at transparency in various ways, and addresses socio-ecological risks by working with wheat suppliers (currently more on durum wheat than on soft wheat).

Information and communication activity is very intense in the global chain, also on sustainability matters. Local ch sustainabily matters. Local chan, relies o

Nutritional value is core in communication strategies of the local chain. The characteristics of raw materials is the most relevant aspect. Also the global chain's strategy focuses on nutritional value. Here the focus is more on recipe adaptation.
Ayala et al. 2012; Bonakele and Mncube 2012; Tsegaye, 2012; Gracia et al. 2010;

El-Lattief, 2011; Louw et al., 2013

Bardsley and Bardsley 2014

Enjalbert et al. 201
Not available Not enough data to give a reasonable judgement

Local chain has turned to ancient wheat varieties, organic agriculture and alternative food networks to differentiate and limit dependence from policy support. The global chain searches for integration with wheat suppliers to improve resilience and address socio-ecological risks. 
Table 2 Sustainability attributes for the wheat to bread chain and assessment on difference and performance (Continued)

\begin{tabular}{|c|c|c|c|c|}
\hline Resource use and pollution & $\begin{array}{l}\text { Environmental impacts of bread production } \\
\text { at different scales (industrial, artisanal, home), } \\
\text { of different baking methods and other } \\
\text { parameters: country of origin of wheat, } \\
\text { production method, type of flour, type of } \\
\text { packaging (plastic and paper bags), } \\
\text { bread losses and waste }\end{array}$ & $\begin{array}{l}\text { Andersson, 2000; Andersson and Ohlsson 1999; } \\
\text { Espinoza-Orias et al., 2011; Jury et al. 2011; } \\
\text { Meisterling et al. 2009; Williams et al. 2010; } \\
\text { Moudrý et al. 2013; Yadav and Marshall, } \\
\text { 2011; Williams and Wikström 2011; } \\
\text { Koskela et al., 2014; Ruini et al. } 2013\end{array}$ & ++ & $\begin{array}{l}\text { LCA studies available for the global bread } \\
\text { show that resource use and pollution are } \\
\text { lowest for this chain. The comparison based } \\
\text { on emissions and energy use per kg. tend } \\
\text { to advantage larger scale productions. }\end{array}$ \\
\hline Responsibility & $\begin{array}{l}\text { Corporate social responsibility of processors } \\
\text { and retailers. Subsidies and social/ } \\
\text { political stability }\end{array}$ & $\begin{array}{l}\text { Magnan, 2011; Forsman-Hugg et al. 2013; } \\
\text { Salevurakis and Abdel-Haleim } 2008\end{array}$ & ++ & $\begin{array}{l}\text { Global chain provides a corporate social } \\
\text { responsibility report annually. The local } \\
\text { chain is also third party monitored for } \\
\text { being organic, and "socially"-monitored } \\
\text { by direct relationships. }\end{array}$ \\
\hline \multirow[t]{2}{*}{ Safety } & $\begin{array}{l}\text { Food safety challenges of traditional foods } \\
\text { and role of good manufacturing practices }\end{array}$ & \multirow[t]{2}{*}{$\begin{array}{l}\text { Lücke and Zangerl, 2014; Vidal et al., } \\
\text { 2014; Cauvain, 2012; Sharma et al. } 2005\end{array}$} & \multirow[t]{2}{*}{+} & \multirow{2}{*}{$\begin{array}{l}\text { Safety must be guaranteed in all chains } \\
\text { considered, with differing constraints } \\
\text { depending on context. }\end{array}$} \\
\hline & $\begin{array}{l}\text { Effects of sourdough fermentation on } \\
\text { mycotoxins. Dissipation of pesticides } \\
\text { during bread making }\end{array}$ & & & \\
\hline Technological innovation & $\begin{array}{l}\text { Genetic improvement of wheat cultivars, } \\
\text { yield improvement; innovations in machinery } \\
\text { for milling and bread processing; standardization } \\
\text { of sourdough technology; innovation related } \\
\text { to health, pleasure, and convenience }\end{array}$ & $\begin{array}{l}\text { Martínez-Monzó et al. 2013; Campbell } \\
\text { et al. 2012; Skudra and Linina, 2011; } \\
\text { Moroni et al. 2010; Sener et al. 2009; } \\
\text { Clarke and Arendt, 2005; Rolfo et al. } 1993 .\end{array}$ & ++ & $\begin{array}{l}\text { Global chains has resources that allow } \\
\text { continuous innovation. Local chain is very } \\
\text { advanced related to its context and } \\
\text { resources available (i.e. milling plant) }\end{array}$ \\
\hline Territoriality & $\begin{array}{l}\text { Locally adapted bread varieties and ancient } \\
\text { grains. Willingness to pay for locality and organic. }\end{array}$ & Naspetti and Bodini, 2008; Pasqualone, 2013a & +++ & $\begin{array}{l}\text { Local bread reflects a strong link to } \\
\text { territory and traditions. }\end{array}$ \\
\hline \multirow[t]{2}{*}{ Traceability } & $\begin{array}{l}\text { Ethical aspects of traceability and communication } \\
\text { to the consumer }\end{array}$ & \multirow[t]{2}{*}{$\begin{array}{l}\text { Barling et al., 2009; Magnan, 2011; } \\
\text { Pasqualone 2013b,c }\end{array}$} & \multirow[t]{2}{*}{+++} & \multirow{2}{*}{$\begin{array}{l}\text { Local chain is de facto traceable, accessible } \\
\text { and transparent. The global chain aims at } \\
\text { increasing transparency and direct contact } \\
\text { to consumer. }\end{array}$} \\
\hline & $\begin{array}{l}\text { Shift towards higher quality and identity } \\
\text { preserved wheat (varietal traceability) }\end{array}$ & & & \\
\hline
\end{tabular}


Table 2 Sustainability attributes for the wheat to bread chain and assessment on difference and performance (Continued)

\begin{tabular}{|c|c|c|c|c|}
\hline \multirow[t]{3}{*}{ Waste } & Identification of bread waste determinants & \multirow{3}{*}{$\begin{array}{l}\text { Vandermeersch et al., 2014; Fadda et al. } \\
\text { 2014; Freedman and Bartoli 2013; } \\
\text { Espinoza-Orias et al. 2011; Williams and } \\
\text { Wikström 2011; Mohammadi, 2007; } \\
\text { Rosing and Nielsen, 2004; } \\
\text { Andersson and Ohlsson } 1999\end{array}$} & \multirow[t]{3}{*}{+} & \multirow{3}{*}{$\begin{array}{l}\text { Both chains show low levels of waste for } \\
\text { different reasons. Both breads have a long } \\
\text { shelf life: local bread can be re-used in } \\
\text { typical recipes, global bread has a } \\
40 \text { days shelf life }\end{array}$} \\
\hline & $\begin{array}{l}\text { Innovation to retard bread staling and } \\
\text { role of packaging for preventing } \\
\text { bread loss }\end{array}$ & & & \\
\hline & $\begin{array}{l}\text { Bread waste valorization options } \\
\text { (and environmental impacts) }\end{array}$ & & & \\
\hline
\end{tabular}

aThe column "Differences" expresses high (+++), medium (++), low (+) differences between local and global bread chains 
much less costly communication strategy occurs, based on the "word of mouth" and direct social relationships. The role of trust between consumers and producer plays here a crucial role, and it is strongly related to the territorial identity of products and processes. The nutritional value of the local bread is object of particularly intense information transfers, also supported by the collaborations of supply chains with researchers - also in the medical fields - although there isn't any formal nutritional claim on the products.

\section{Conclusions}

This paper delivers a literature review around the sustainability of wheat-to-bread chains, proposes a set of sustainability assessment criteria, and identifies major critical aspects of two Italian case studies, thus resulting is a case study-based qualitative assessment. Our analysis pinpoints chains attributes that help discriminate local and global food systems for their overall sustainability. Among the investigated food attributes, nutritional quality and waste deserve further investigation. Nutritional quality is key in human health and associated to most production chain phases, as well as with consumption patterns, consumer sensitivity to health issues and retail price. The attribute "waste" has a marginal importance for the sustainability of the investigated case studies, thus contrasting with the intuitive relevance of food waste and the high importance within the academic literature and the policy discourse. The outcome of our research support previous studies (e.g. Barling et al., 2009; Lusk and Briggeman, 2009) by highlighting that ethical attributes, such e.g. environmental impact and traceability, can significantly affect consumer purchasing behaviour. A major limitation of this work is the inevitably partial literature review: we cannot claim to have included all relevant academic studies. Despite having aimed at transparency and objectivity, the present assessment resulted from Authors' judgment. In addition, our results are based on two Italian case studies, which makes generalization hardly viable. Those two case studies were identified as examples of a local and a global food system, thus not being representative for neither the huge internal variability of both local and global supply-chains, nor of food systems with intermediate characteristics. These intermediate food systems also deserve sustainability assessments. Further research comparing food chains with different geographical scope over multiple dimensions of sustainability would help the validity of our study. The methodological framework that we deliver can help identify issues to deal with and critical gaps, thus representing a starting point for further empirical research. Particularly, attributes could be evaluated using weighting factors; supply chain stakeholders could be involved via participatory methods, such e.g. participatory checklists. In addition, using measurable indicators to approximate the impact of subsets of attributes on food chain sustainability will help research objectivity and comparability.

\section{Endnotes}

${ }^{1}$ It is worth emphasizing that the comparison is focused on supply chains and not on the final products of the two selected cases, which are extremely diverse, both in terms of intrinsic quality and price.

${ }^{2}$ We have dropped animal welfare and fair trade and joined closely related attributes. In particular: resource use and pollution; resilience and local development; connection and labour relations. 


\title{
${ }^{3}$ World Food System Center, ETH, Zurich. http://www.worldfoodsystem.ethz.ch/re- search/CRP.html accessed on 3/2/2015.
}

\author{
Abbreviation \\ AFN: Alternative Food Networks; NGO: Non-governative organization; PDO: Protected Designation of Origin; \\ PGI: Protected Geographical Indication; WFSC: World Food System Center.
}

\section{Competing interests}

The authors declare that they have no competing interests.

\section{Authors' contributions}

FG carried out the systematic review, interviews and data collection and wrote the Methods and the Discussion sections. OG wrote the background section. FB wrote "The bread sector in Italy" section, AM wrote "Mapping the global chain case study" section and SG wrote "Mapping the local chain case study" section. LC contributed to the conclusions, together with all other authors. GB conceived, designed and coordinated the study. All authors critically revised and approved the manuscript.

\section{Acknowledgments}

The research reported in this paper was funded by the EU within the project Global and Local food chain Assessment: a Multidimensional performance-based approach (GLAMUR, 7th Framework Program). Further information is available on the website http://www.glamur.eu/. The views expressed in this paper are solely those of the authors.

\section{Author details}

${ }^{1}$ Department of Agriculture, Food and Environment, University of Pisa, via del Borghetto 80, 56124 Pisa, Italy.

${ }^{2}$ Fondazione Italiana per la Ricerca in Agricoltura Biologica e Biodinamica c/o Città dell'Altra Economia, Largo Dino Frisullo snc, 00153 Rome, Italy. ${ }^{3}$ Department of Economics and Management, University of Florence, Via delle Pandette 9, Edificio, D6 - 50127 Florence, Italy.

Received: 12 February 2015 Accepted: 31 July 2015

Published online: 25 August 2015

\section{References}

Ahmed M, Hassan FU, Asif M (2012) Physiological response of bread wheat (Triticum aestivum L.) to high temperature and moisture stresses. Aust J Crop Sci 6(4):749-755

Andersson K (2000) LCA of food products and production systems. Int J Life Cycle Assess 5(4):239-248

Andersson K, Ohlsson T (1999) Life cycle assessment of bread produced on different scales. Int J Life Cycle Assess 4(1):25-40

Annett LE, Muralidharan V, Boxall PC, Cash SB, Wismer WV (2008) Influence of health and environmental information on hedonic evaluation of organic and conventional bread. J Food Sci 73(4):H50-H57

Antúnez L, Vidal L, Sapolinski A, Giménez A, Maiche A, Ares G (2013) How do design features influence consumer attention when looking for nutritional information on food labels? Results from an eye-tracking study on pan bread labels. Int J Food Sci Nutr 64(5):515-527

Ayala GX, Laska MN, Zenk SN, Tester J, Rose D, Odoms-Young A, McCoy T, Gittelsohn J, Foster GD, Andreyeva T (2012) Stocking characteristics and perceived increases in sales among small food store managers/owners associated with the introduction of new food products approved by the Special Supplemental Nutrition Program for Women, Infants, and Children. Public Health Nutr 15(9):1771-1779

Azapagic A, Stichnothe H, Espinoza-Orias N (2010) Sustainability Issues in Food Provisioning Systems, Sustainable Development in Practice: Case Studies for Engineers and Scientists., pp 326-347

Bardsley DK, Bardsley AM (2014) Organising for socio-ecological resilience: The roles of the mountain farmer cooperative Genossenschaft Gran Alpin in Graubünden, Switzerland. Ecol Econ 98:11-21

Barham E, Sylvander B (2011) Labels of origin for food. Local development, global recognition, Cab International

Barilla, (2012) Environmental Product Declaration of soft wheat Pan Bauletto Bianco. http://gryphon.environdec.com/ data/files/6/8171/epd223.pdf. Accessed on 3/2/2015

Barling D, Sharpe R, Lang T (2009) Traceability and ethical concerns in the UK wheat-bread chain: From food safety to provenance to transparency. Int J Agr Sustain 7(4):261-278

Barnett C, Cloke P, Clarke N, Malpass A (2010) Globalizing responsibility: The political rationalities of ethical consumption. John Wiley \& Sons, Chichester

Barre DE, Mizier-Barre E, Macintyre P (2011) Socioeconomic Factors and Their Relation to Eating Habits in Two Communities in Nova Scotia, Canada. J Hunger Environ Nutr 6(4):497-505

Békés F (2012) New aspects in quality related wheat research: II. New methodologies for better quality wheat. Cereal Res Commun 40(3):307-333

Belz MCE, Ryan LAM, Arendt EK (2012) The Impact of Salt Reduction in Bread: A Review. Crit Rev Food Sci Nutr 52(6):514-524

Bonakele T, Mncube L (2012) Designing appropriate remedies for competition law enforcement: The pioneer foods settlementagreement. J Competition Law Econ 8(2):425-447

Bonneuil C, Goffaux R, Bonnin I, Montalent P, Hamon C, Balfourier F, Goldringer I (2012) A new integrative indicator to assess crop genetic diversity. Ecol Indic 23:280-289

Bonnin I, Bonneuil C, Goffaux R, Montalent P, Goldringer I (2014) Explaining the decrease in the genetic diversity of wheat in France over the 20th century. Agric Ecosyst Environ 195:183-192

Cacchiarelli L, D. A. Lass, and A. Sorrentino. "CAP reform and price transmission in the pasta chain." 2013 Second Congress, June 6-7, 2013, Parma, Italy. No. 149925. Italian Association of Agricultural and Applied Economics (AlEAA), 2013. 
Campbell GM, Webb C, Owens GW, Scanlon MG (2012) Milling and flour quality, Secondth edn, Breadmaking: Improving quality., pp 188-215

Caraher M, Lloyd S, Lawton J, Singh G, Horsley K, Mussa F (2010) A tale of two cities: A study of access to food, lessons for public health practice. Health Educ J 69(2):200-210

Cauvain SP (2012) Introduction to breadmaking, Secondth edn, Breadmaking: Improving quality., pp 1-8

Clarke Cl, Arendt EK (2005) A Review of the Application of Sourdough Technology to Wheat Breads. Adv Food Nutr Res 49:137-161

Coda R, Cagno RD, Gobbetti M, Rizzello CG (2014) Sourdough lactic acid bacteria: Exploration of non-wheat cerealbased fermentation. Food Microbiol 37:51-58

Dawson JC, Serpolay E, Giuliano S, Schermann N, Galic N, Chable V, Goldringer I (2012) Multi-trait evolution of farmer varieties of bread wheat after cultivation in contrasting organic farming systems in Europe. Genetica 140(1-3):1-17

Dewettinck KA, Van Bockstaele FAB, Kühne BC, Van de Walle DA, Courtens TMA, Gellynck XC (2008) Nutritional value of bread: Influence of processing, food interaction and consumer perception. J Cereal Sci 48(2):243-257

Durham CA, King RP, Roheim CA (2009) Consumer Definitions of 'Locally Grown' for Fresh Fruits and Vegetables. J Food Distrib Res 2009(40):56-62

Duvenage SS, Schönfeldt HC (2007) Impact of South African fortification legislation on product formulation for low-income households. J Food Compos Anal 20(8):688-695

El-Lattief EAA (2011) Bread wheat (Triticum aestivum L.) productivity and profitability as affected by method of sowing and seeding rate under Qena environment. Asian J Crop Sci 3(4):188-196

Enjalbert J, Dawson JC, Paillard S, Rhoné B, Rousselle Y, Thomas M, Goldringer I (2011) Dynamic management of crop diversity: From an experimental approach to on-farm conservation. Comptes Rendus - Biologies 334(5-6):458-468

Espinoza-Orias N, Stichnothe H, Azapagic A (2011) The carbon footprint of bread. Int J Life Cycle Assess 16(4):351-365

Fadda C, Sanguinetti AM, Del Caro A, Collar C, Piga A (2014) Bread staling: Updating the view. Comprehensive Reviews in Food Science and Food Safety 13(4):473-492

Falco SD, Smale M, Perrings C (2008) The role of agricultural cooperatives in sustaining the wheat diversity and productivity: The case of southern Italy. Environ Resour Econ 39(2):161-174

Fink A (2014) Conducting research literature reviews. From the Internet to paper, 4th edn. Sage, Thousand Oaks

Flynn MA, O'Brien CM, Ross V, Flynn CA, Burke SJ (2012) Revision of food-based dietary guidelines for Ireland, Phase 2: recommendations for healthy eating and affordability. Public Health Nutr 15(03):527-537

Forsman-Hugg S, Katajajuuri J-M, Riipi I, Mäkelä J, Järvelä K, Timonen P (2013) Key CSR dimensions for the food chain. Br Food J 115(1):30-46

Forssell S, Lankoski L (2014) The sustainability promise of alternative food networks: an examination through "alternative" characteristics. Agr Hum Values 32:1-13

Freedman MR, Bartoli C (2013) Food Intake Patterns and Plate Waste Among Community Meal Center Guests Show Room for Improvement. J Hunger Environ Nutr 8(4):506-515

Gallo G, Lo Bianco M, Bognanni R, Saimbene G, Orlando A, Grillo O, Saccone R, Venora G (2009) Durum wheat bread: Old sicilian varieties and improved ones, 5th International Technical Symposium on Food Processing, Monitoring Technology in Bioprocesses and Food Quality Management., pp 1128-1138

Gava O, Bartolini F, Brunori G, Galli F (2014) Sustainability of local versus global bread supply chains: a literature review. Paper prepared for presentation at the 3rd AIEAA Conference "Feeding the Planet and Greening Agriculture: Challenges and opportunities for the bio-economy", Alghero, Italy.

Gellynck X, Molnár A (2009) Chain governance structures: the European traditional food sector. Brit Food J 111(8):762-775

Gellynck X, Kühne B, Van Bockstaele F, Van de Walle D, Dewettinck K (2009) Consumer perception of bread quality. Appetite 53(1):16-23

Goodman MK, Maye D, Holloway L (2010) Ethical foodscapes: premises, promises and possibilities. Environ Plann A 42:1782-1796

Gracia A, de Magistris T, \& Albisu LM (2010) Inter-organizational relationships as determinants for competitiveness in the agri-food sector: The Spanish wheat-to-bread chain. In C. Fisher \& M. Hartmann (Eds.), Oxfordshire, UK: CAB International. Agri-food chain relationshis., pp. 206-219.

Hand MS, Martinez S (2010) Just what does local mean. Choices 25(1):13-18

He Z, Joshi AK, Zhang W (2013) Climate Vulnerabilities and Wheat Production. Climate Vulnerability: Understanding and Addressing Threats to Essential Resources 2:57-67

Hellyer NE, Fraser I, Haddock-Fraser J (2012) Food choice, health information and functional ingredients: An experimental auction employing bread. Food Policy 37(3):232-245

Hills KM, Goldberger JR, Jones SS (2013) Commercial bakers and the relocalization of wheat in western Washington State. Agr Hum Values 30(3):365-378

Hogan L, Thorpe S (2009) Issues in Food Miles and Carbon Labeling. Australian Bureau of Agricultural and Resource Economics, Canberra, Australia

IGD (2008) Ethical Shopping in Europe. IGD, Radlett, Herts

Ilbery B, Maye D (2005) Food supply chains and sustainability: evidence from specialist food producers in the Scottish/ English borders. Land Use Policy 22(4):331-344

Ilbery B, Maye D (2006) Retailing local food in the Scottish-English borders: A supply chain perspective. Geoforum 37(3):352-367

Jat RK, Sapkota TB, Singh RG, Jat ML, Kumar M, Gupta RK (2014) Seven years of conservation agriculture in a rice-wheat rotation of Eastern Gangetic Plains of South Asia: Yield trends and economic profitability. Field Crop Res 164(1):199-210

Jones JM (2011) The whole-grain conundrum. Cereal Foods World 56(3):124-127

Jury V, Janestad H, Davis J, Ahrń L (2011) Processes impact in life cycle assessment of bread, 6th International CIGR Technical Symposium - Towards a Sustainable Food Chain: Food Process, Bioprocessing and Food Quality Management., p 4

Katina K, Arendt E, Liukkonen K-H, Autio K, Flander L, Poutanen K (2005) Potential of sourdough for healthier cereal products. Trends Food Sci Technol 16(1-3):104-112 
Khatir Z, Paton J, Thompson H, Kapur N, Toropov V (2013) Optimisation of the energy efficiency of bread-baking ovens using a combined experimental and computational approach. Appl Energy 112:918-927

Kihlberg I, Johansson L, Langsrud Ø, Risvik E (2005) Effects of information on liking of bread. Food Qual Prefer 16(1):25-35

Kimura SD, Toma Y, Mu Z, Yamada H, Hatano R (2010) Eco-balance analysis of land use combinations to minimize environmental impacts and maximize farm income in northern Japan. Sustain Sci 5(1):19-27

Kirwan J, Maye D, Bundwhoo D, Keech D, Brunori G, (2014) Scoping/framing general comparative report on food chain performance, Deliverable 2.3, Glamur (Global and Local food chain Assessment: a Multidimensional performancebased approach" $7^{\text {th }}$ FP, Grant agreement no: 311778 .

Kneafsey M, Venn L, Schmutz U, Balázs B, Trenchard L, Eyden-Wood T, Bos E, Sutton G, Blackett M (2013) Short Food Supply Chains and Local Food Systems in the EU. A State of Play of their Socio-Economic Characteristics. Joint Research Centre, Report EUR 25911 EN.

Koskela S, Dahlbo H, Judl J, Korhonen M-R, Niininen M (2014) Reusable plastic crate or recyclable cardboard box? A comparison of two delivery systems. J Clean Prod 69:83-90

Li X-N, Rui L (2013) The effect of grain subsidies on the production and farmers' income in China, International Conference on Management Science and Engineering - Annual Conference Proceedings

Lopez-Class M, Hosler AS (2010) Assessment of community food resources: A Latino neighborhood study in upstate New York. J Poverty 14(4):369-381

Louw A, Troskie G, Geyser M (2013) Small millers and bakers perceptions of the limitations of agro-processing development in the wheat-milling and baking industries in rural areas in South Africa. Agrekon 52(3):101-122

Lücke F-K, Zangerl P (2014) Food safety challenges associated with traditional foods in German-speaking regions. Food Control 43:217-230

Lusk JL, Briggeman BC (2009) Food values. American Journal of Agricultural Economics, 91(1):184-196.

Magnan A (2011) Bread in the Economy of Qualities: The Creative Reconstitution of the Canada-UK Commodity Chain for Wheat. Rural Sociol 76(2):197-228

Marsden T (2000) Food Matters and the Matter of Food: Towards a New Food Governance? Sociol Ruralis 40(1):20-29

Marsden T, Smith E (2005) Ecological entrepreneurship: sustainable development in local communities through quality food production and local branding. Geoforum 36(4):440-451

Martinez S, Hand M, Da Pra M, Pollack S, Vogel S, Clark S, Lohr R, Low S, Newman C, Ralston K, Smith T (2010) Local Food Systems. Concepts, Impacts, and Issues. USDA Economic Research Service, Report n.97.

Martínez-Monzó J, García-Segovia P, Albors-Garrigos J (2013) Trends and innovations in bread, bakery, and pastry. J Culinary Sci Technol 11(1):56-65

Mason NM, Jayne TS, Chapoto A, Donovan C (2011) Putting the 2007/2008 global food crisis in longer-term perspective: Trends in staple food affordability in urban Zambia and Kenya. Food Policy 36(3):350-367

Maye D, Kirwan J (2010) Alternative food networks, Sociology of agriculture and food entry for Sociopedia.isa. Sage, Thousand Oaks

Meisterling K, Samaras C, Schweizer V (2009) Decisions to reduce greenhouse gases from agriculture and product transport: LCA case study of organic and conventional wheat. J Clean Prod 17(2):222-230

Ménard C, Valceschini E (2005) New institutions for governing the agri-food industry. Eur Rev Agric Econ 32(3):421-440

Milestad R, Bartel-Kratochvil R, Leitner H, Axmann P (2010) Being close: The quality of social relationships in a local organic cereal and bread network in Lower Austria. J Rural Stud 26(3):228-240

Mohammadi IM (2007) Factors influencing wheat, flour, and bread waste in Iran. J New Seeds 8(4):67-78

Mondal A, Datta AK (2008) Bread baking a review. J Food Eng 86(4):465-474

Mooney PH, Scott AH (2009) Food Security: The Elaboration of Contested Claims to a Consensus Frame. Rur Soc 74(4):469-497

Moroni AV, Arendt EK, Morrissey JP, Bello FD (2010) Development of buckwheat and teff sourdoughs with the use of commercial starters. Int J Food Microbiol 142(1-2):142-148

Moudrý J Jr, Jelínková Z, Plch R, Moudrý J, Konvalina P, Hyšpler R (2013) The emissions of greenhouse gases produced during growing and processing of wheat products in the Czech Republic. J Food Agric Environ 11(1):1133-1136

Mujeeb-Kazi A, Kazi AG, Dundas I, Rasheed A, Ogbonnaya F, Kishii M, Bonnett D, Wang RR-C, Xu S, Chen P, Mahmood T, Bux H, Farrakh S (2013) Genetic diversity for wheat improvement as a conduit to food security. Adv Agron 122:179-257

Naspetti S, Bodini A (2008) Consumer perception of local and organic products: Substitution or complementary goods? Int J Interdiscip Soc Sci 3(2):111-121

O'Hara SU, Stagl S (2001) Global food markets and their local alternatives: A socio-ecological economic perspective. Population and Environment. J Interdiscip Stud 22(6):533-554

Olaoye OA, Ade-Omowaye BIO, Preedy VR, Watson RR, Patel VB (2011) Composite flours and breads: potential of local crops in developing countries. Flour and breads and their fortification in health and disease prevention., pp 183-192

Ortiz-Monasterio RJl, Sayre KD, Rajaram S, McMahon M (1997) Genetic progress in wheat yield and nitrogen use efficiency under four nitrogen rates. Crop Sci 37(3):898-904

Özbek Ö (2014) Turkish wheat landraces: Population structure and function. Emirates J Food Agric 26(2):137-148

Ozola L, Straumite E (2012) Consumers' attitude towards availability and quality of gluten-free products in the latvian market. Res Rural Dev 1:149-154

Pagani MA, Lucisano M, Mariotti M (2014) Italian Bakery Products. Bakery Products Science and Technology, Secondth edn., pp 685-721. doi:10.1002/9781118792001.ch40

Pan Y, Yu Z, Holst J, Doluschitz R (2014) Integrated assessment of cropping patterns under different policy scenarios in Quzhou County, North China Plain. Land Use Policy 40:131-139

Pasqualone, A (2013a) Italian durum wheat breads. Bread Consumption and Health, pp. 56-79

Pasqualone, A (2013b) Italian durum wheat breads. Bread Consumption and Health, pp. 56-79

Pasqualone, A (2013c) Cultivar identification and varietal traceability in processed foods: A molecular approach. Cultivars: Chemical Properties, Antioxidant Activities and Health Benefits, pp. 83-105

Penker M (2006) Mapping and measuring the ecological embeddedness of food supply chains. Geoforum 37(3):368-379 
Pfau SF, Hagens JE, Dankbaar B, Smits AJ (2014) Visions of Sustainability in Bioeconomy Research. Sustainability 6(3):1222-1249

Pimentel D, Marklein A, Toth MA, Karpoff MN, Paul GS, McCormack R, Kyriazis J, Krueger T (2009) Food versus biofuels: Environmental and economic costs. Hum Ecol 37(1):1-12

Pretty J, Ball AS, Lang T, Morison JIL (2005) Farm costs and food miles: An assessment of the full cost of the UK weekly food basket. Food Policy 30:1-19

Rolfo S, Vaglio P, Vitali G (1993) Small firms and technological development in the food processing machinery industry: The case of pasta and other cereal derivative machines in Italy. Small Bus Econ 5(4):307-317

Rosing L, Nielsen AM (2004) When a hole matters - the story of the hole in a bread for French hotdog. In: Halberg N (ed) Life Cycle Assessment in the Agri-food sector. Pro- ceedings of the 4th International Conference, October 6-8, 2003, Horsens, Denmark

Ruini L, Marino M, Pignatelli S, Laio F, \& Ridolfi L (2013) Water footprint of a large-sized food company: the case of Barilla pasta production. Water Resources and Industry, 1, 7-24.

Rumánková L (2014) Asymmetry in Price Transmission of the Czech Wheat Agri-food Chain. AGRIS on-line Papers in Economics and Informatics 6(1):63-71

Salevurakis WJ, Abdel-Haleim SM (2008) Bread subsidies in Egypt: Choosing social stability or fiscal responsibility. Review of Radical Political Economics 40(1):35-49

Schenk J, Hellegers P, van Asseldonk M, Davidson B (2014) How do farmers react to varying water allocations? An assessment of how the attitude to risk affects farm incomes. Agric Water Manag 136:52-58

Selfa T, Qazi J (2005) Place, taste, or face-to-face? Understanding producer-consumer networks in "local" food systems in Washington State. Agr Hum Values 22(4):451-464

Sener O, Arslan M, Soysal Y, Erayman M (2009) Estimates of relative yield potential and genetic improvement of wheat cultivars in the Mediterranean region. J Agric Sci 147(3):323-332

Sharma J, Satya S, Kumar V, Tewary DK (2005) Dissipation of pesticides during bread-making. Chem Health Saf 12(1):17-22

Skudra I, Linina A (2011) The influence of meteorological conditions and nitrogen fertilizer on wheat grain yield and quality, 6th Baltic Conference on Food Science and Technology: Innovations for Food Science and Production, FOODBALT-2011 - Conference Proceedings., pp 23-26

Smith ML, Sunil TS, Salazar CI, Rafique S, Ory MG (2013) Disparities of food availability and affordability within convenience stores in Bexar County, Texas. J Environ Public Health 2013:782756

Sternberg T (2012) Chinese drought, bread and the Arab Spring. Appl Geogr 34(4):519-524

Talaei MAB, Mohammadifard NA, Khaje M-RC, Sarrafzadegan NA, Sajjadi FA, Alikhasi HA, Maghroun MA, Iraji FD, Ehteshami SD (2013) Healthy bread initiative: Methods, findings, and theories-isfahan healthy heart program. $J$ Health Popul Nutr 31(1):49-57

Tregear A, Arfini F, Belletti G, Marescotti A (2007) Regional foods and rural development: the role of product qualification. J Rural Stud 23:12-22

Tsegaye D (2012) Profitability of contractual bread wheat seed production in Mecha district of Amhara region, Ethiopia. J Cent Eur Agric 13(1):142-149

Vandermeersch T, Alvarenga RAF, Ragaert P, Dewulf J (2014) Environmental sustainability assessment of food waste valorization options. Resour Conserv Recycl 87:57-64

Vidal A, Marín S, Morales H, Ramos AJ, Sanchis V, Vidal A, Marín S, Morales H, Ramos AJ, Sanchis V (2014) The fate of deoxynivalenol and ochratoxin $A$ during the breadmaking process, effects of sourdough use and bran content. Food Chem Toxicol 68:53-60

Williams H, Wikström F (2011) Environmental impact of packaging and food losses in a life cycle perspective: A comparative analysis of five food items. J Clean Prod 19(1):43-48

Williams AG, Audsley E, Sandars DL (2010) Environmental burdens of producing bread wheat, oilseed rape and potatoes in England and Wales using simulation and system modeling. Int J Life Cycle Assess 15(8):855-868

Wiskerke JSC (2003) On promising niches and constraining socio-technical regimes: the case of Dutch wheat and bread. Environ Plann 35(3):429-448

Yadav RS, Marshall RJ (2011) Understanding product carbon footprint and waste management in sandwich manufacturing, 6th International CIGR Technical Symposium - Towards a Sustainable Food Chain: Food Process, Bioprocessing and Food Quality Management., p 6

Yusufali R, Sunley N, de Hoop M, Panagides D (2012) Flour fortification in South Africa: post-implementation survey of micronutrient levels at point of retail. Food Nutr Bull 33(4 Suppl):S321-329

\section{Submit your manuscript to a SpringerOpen ${ }^{\circ}$ journal and benefit from:}

- Convenient online submission

- Rigorous peer review

- Immediate publication on acceptance

- Open access: articles freely available online

- High visibility within the field

- Retaining the copyright to your article

Submit your next manuscript at $\boldsymbol{\wedge}$ springeropen.com 